\title{
Kasa Invaze Olmayan Mesane Kanserinde Tur-Tm Sırasında Mesane Perforasyonu: Hastaya Erken ve Geç Dönemde Yaklaşım
}

\section{Bladder Perforation During TUR of Non Muscle Invasive Bladder Tumours: Early and Late Management}

\author{
Dr. Deniz Arslan \\ Dr. Suat Seren Göğüs Hastalıkları Hastanesi Üroloji Kliniği, Izmir, Türkiye
}

\begin{abstract}
Özet
Mesane tümörü tanı ve tedavisinde sistoskopi ve transüretral rezeksiyon altın standarttır. Transüretral Rezeksiyon (TUR-Tm) yapılırken mesane perforasyonu oluşabilecek komplikasyonlardan biridir. Mesane perforasyonlarının büyük kısmı ek bir cerrahi girişim gerektirmeksizin tedavi edilmektedir. Erken dönemde çok ciddi sonuçları olmamakla beraber bu hastaların Perforasyon gelişmeyen hastalara oranla kısa zamanda tekrar operasyon ya da uzak metastazlar yönünden yakın takibi önerilmektedir. (Üroonkoloji Bülteni 2014;13:119-121)
\end{abstract}

Anahtar Kelimeler: Mesane kanseri, transüretral rezeksiyon, komplikasyon, mesane perforasyonu

\begin{abstract}
Summary
Cystoscopy and transurethral resection is the gold standard for the diagnosis and treatment of bladder tumors. However, bladder perforation is one of the complications of transurethral resection. But the majority of bladder perforation do not require any additional surgical intervention. Serious adverse outcome of bladder perforation are uncommon in the early period. However, the risk still exists, and the urologist should be aware of the possibility of local and/or distant recurrences. Thus, these patients should be more closely followed up compared to those who did not develop perforation. (Bulletin of Urooncology 2014;13:119-121)
\end{abstract}

Key Words: Bladder cancer, transurethral resection, complications, bladder perfor

\section{Giriş}

Mesane Tümörleri üriner sistemin en sık görülen tümörüdür. Her yıl Amerika Birleşik Devletlerinde ortalama 40,000 yeni olgu bildirilmektedir (1). Bu tümörlerin yaklaşık \%75-\%85'i mukoza (Ta, CIS) veya submukoza (T1) ile sınırlı olup yüzeyel mesane tümörleri (kasa invaze olmayan mesane kanseri) olarak adlandırılırlar. Bu yüzeyel tümörlerin de yaklaşık \%70'i Ta evrede \%20'si T1 evrede ve \%20'si CIS evresindedir (2).

Mesane tümörlerinde hem tanıyı kesinleştirmek için hem de tedavi için primer yöntem Transüretral rezeksiyondur (TURTm) (1). Transüretral rezeksiyon yöntemi tümörün tamamen ortadan kaldırılmasına olanak sağlarken alınan derin parçalar sayesinde de tümörün kas tabakasına ne kadar invaze olduğu ortaya konulabilmektedir (3). Ancak her cerrahi yöntemde olduğu gibi transüretral rezeksiyon cerrahisi esnasında da bazı komplikasyonlar görülebilmektedir. Bu ameliyatın peroperatif başlıca komplikasyonları, tansfüzyon gerektiren kanama \%3-\%13 ve perforasyon \%1-\%5 olarak bildirilmektedir $(4,5)$. Mesane perforasyonu üriner sistem enfeksiyonu riskini ve ürosepsis riskini iki kat arttırır. Perforasyon ile beraber transüretral ikincil girişim ve transfüzyon gerektiren kanama olasılığı \%13 ten \%24'e kadar çıkmaktadır (5).

Perforasyon riski çeşitli faktörlere bağlı olarak değişmektedir. Örneğin cerrahın tecrübesi ve tümörün mesanede lokalizasyonu perforasyon riskini değiştirebilen faktörlerdir. Özellikle yan duvar tümörleri ve mesane kubbesindeki tümörlerde perforasyon riski yüksek olarak bildirilmektedir (6). Özellikle yan duvar tümörlerinde obturatör refleksi ile perforasyon gelişebilir. Bununla beraber farklı görüşlerde mevcuttur. Örneğin Collado ve ark. yaptıkları çalışmada perforasyon sıklığının tümörün evre, grade ve lokalizasyonundan ziyade 
Deniz Arslan

Kasa Invaze Olmayan Mesane Kanserinde Tur-Tm Sırasında Mesane Perforasyonu: Hastaya Erken ve Geç Dönemde Yaklaşım

\begin{tabular}{|l|l|l|}
\hline Tablo 1. Yüzeyel mesane tümörü rezeksiyonu sırasında perforasyon gelişen hastaların karşılaştırmalı istatistikleri \\
\hline & Skolarikos ve ark. (n=34) & Comploj ve ark. (n=37) \\
\hline & No & No \\
\hline Ortalama yaş & $74,59(53-89)$ & $69,5(37-97)$ \\
\hline Cinsiyet (Erkek/Kadın) & $26 / 8$ & $27 / 10$ \\
\hline Perforasyon yeri (Intraperitoneal/Extraperitoneal) & $5 / 29$ & \\
\hline Tedavi şekli (konservatif/drenaj/açık) & $26 / 4 / 4$ & $35 / 1 / 1$ \\
\hline Tümör yeri (anterior/post/sağ lat/sol lat/tavan/trigon) & $14 / 1 / 6 / 7 / 3 / 3$ & \\
\hline Tümör çapı (3 cm büyük/ 3 cm küçük) & $20 / 14$ & $24 / 12$ \\
\hline Tümör evresi (Ta /T1) & $15 / 19$ & $14 / 23$ \\
\hline Tümör rekürrensi (var/yok) & $17 / 17$ & 0 \\
\hline Extravesical rekürrens (var/yok) & $4 / 30$ & \\
\hline
\end{tabular}

tümör çapı ve sayısı ile doğru orantılı olduğunu bildirmişlerdir (4). Ayrıca TUR esnasında mesanenin aşırı distansiyonu ve alınan parçaların derin ve kalın alınması da perforasyon riskini arttıran faktörlerdendir. Perforasyon nadiren de TUR'u yeni öğrenen kişilerde rezektoskopun fazla itilmesi nedeniyle de gelişebilir (7).

Perforasyon intra yada ekstraperitoneal bölgeye olmak üzere iki şekilde olur. Perforasyonun hangi alana olduğu ile ilgili tereddüt var ise ya da perforasyonun ne boyutta olduğunu tam tespit etmek amacıyla sistografi çekilebilir. Farklı serilerde değişik oranlar olmakla beraber vakaların yaklaşık \%83-\%89 oranında extraperitoneal olduğu bildirilmektedir (8). Hastalar genellikle sadece üretral sonda takılarak 5-7 gün izlem ile başka bir işleme gerek kalmadan tedavi edilir. Nadiren de olsa büyük perforasyon oluşmuş ve buna bağlı fazla miktarda sıvı koleksiyonu oluşmuşsa retzius boşluğuna dren koymak gerekebilir (9).

Intraperitoneal perforasyon daha ciddi bir durumdur. Çünkü bağırsak yaralanması olasılığı ile beraber irrigasyon solusyonunun batın içine yayılıp sistemik emilimi de söz konusu olabilir (10). Bu konudaki geleneksel yaklaşım intraperitoneal perforasyon olduğu anda açık cerrahiye geçilmesi şeklindedir. Karın içi açılarak bağırsaklar kontrol edilir ve herhangi bir yaralanma yok ise serum fizyolojik ile çevresel dokular iyice yıkanarak kapatılır. Son yıllarda perforasyonun tamiri için daha minimal invaziv yaklaşımlar olan perkütan peritoneal drenaj veya laparaskopik yaklaşımlar da önerilmektedir $(11,12)$. Mesane perforasyonu sonrası kalan rezidüel tümörlerin genellikle ilk operasyondan 6 hafta sonra tekrar opere edilmesi önerilmektedir (8).

Perforasyon sonucunda ekstravezikal metastaz ile ilgili literatürde farklı yayınlar mevcuttur. Örneğin Mydlo ve ark. perforasyon gelişen 11 hastadan bir tanesinde yaygın peritoneal metastazlar bildirmiştir (1). Yine aynı şekilde Yap ve Richie transizyonel hücreli karsinom için TUR-Tm yapılan ve perforasyon gelişen ardından da açık mesane tamiri yapılan bir hastada psoas kasında metastaz bildirmişlerdir (13). Bir çok çalışmada da mesane perforasyonuna bağlı ekstravezikal tümör rekürrens insidansı düşük olarak bildirilmektedir. Collado ve ark. yaptıkları çalışmada 36 hastada hiç nüks tespit etmemişlerdir. Bu hastaların \%11'inde perforasyon noktası açık olarak tamir edilmiştir (4). Aynı şekilde Mack ve ark. 12 hastada 15 yıllık takip ile hiç ekstravezikal tümör nüksü tespit etmemişlerdir (14). Ancak Tablo 1'de de görüldüğü üzere literatürde birbirinden farklı sonuçlar da var. Skolarikos ve ark. hastaların $\% 11,8^{\prime}$ inde ekstravezikal nüks bildirmekte iken Copmloj ve ark. hemen aynı sayıdaki hastada hiç nüks tespit etmemişlerdir $(8,9)$. Ancak yine aynı çalışmada Comploj perforasyon hastalarının perfore olmayan hastalara göre mortalite, progresyon ve sistektomi oranlarının yüksek olduğunu tespit etmişlerdir (8).

Perforasyon sonrasında rekürrens oluşmasını önlemek için sistemik veya lokal kemoterapi/radyoterapi tedavisi ile ilgili kesin görüşler yoktur. Ancak çeşitli hayvan çalışmalarında intraperitoneal tümör enjekte edildiğinde Gemcitabine ve doxorubicinin fibrinolitik ajanlarla kombinasyonunun tümör hücrelerinin büyümesini durdurduğu gösterilmiştir (15).

\section{Sonuç}

Tüm diğer branşlarda olduğu gibi ürolojik cerrahi de komplikasyonları olan bir alandır. Mesane tümörü için transüretral cerrahi çok sıklıkla yapılan ürolojik ameliyatlardan biridir. Mesane perforasyonu bu komplikasyonlardan biridir. Perforasyon her cerrahın yaşayabileceği bir durumdur. Özellikle mesane yan duvar, tavan ve posterior tümörlerini alırken dikkatli olmalı. Mesaneyi aşırı doldurmaktan kaçınmalı ve çok fazla derin parçalar almak için acele etmemelidir. Her ne kadar perforasyon riski olsa da lokal veya uzak metastaz olasılığının düşük olduğu bilinmelidir.

\section{Kaynaklar}

1. Mydlo JH, Weinstein $\mathrm{R}$, Shah $\mathrm{S}$, et al. Long-term consequences from bladder perforation and/or violation in the presence of transitional cell carcinoma: results of a small series and a review of the literature. J Urol 1999;161:1128-1132. 
2. Soloway MS. It is time to abandon the "superficial" in bladder cancer. Eur Urol 2007;52:1564-1565.

3. Babjuk M, Oosterlinck W, Sylvester R, et al. EAU guidelines on non-muscle-invasive urothelial carcinoma of the bladder. Eur Urol 2008;54:303-314.

4. Collado A, Chechile GE, Salvador J, et al. Early complications of endoscopic treatment for superficial bladder tumors. J Urol 2000; 165:1529-1532.

5. Dick A, Barnes R, Hadley $\mathrm{H}$, et al. Complications of transurethral resection of bladder tumors: prevention, recognition and treatment. J Urol 1980;124:810-814.

6. Balbay MD, Cimentepe E, Unsal A, et al. The actual incidence of bladder perforation following transurethral bladder surgery. J Urol 2005; 174:2260-2262.

7. Green FL, Page DL, Fleming ID, et al. AJCC cancer staging manual 6th edn.springer New York; 2002:335-340.

8. Comploj E, Dechet $C B$, Mian M, et al. Perforation during TUR of bladder tumours influences the natural history of superficial bladder cancer. World J Urol 2013.
9. Skolarikos A, Chrisofos M, Ferakis N, et al. Does the management of bladder perforation during transurethral resection of superficial bladder tumors predispose to extravesical tumor recurrence? J Urol 2005;173:1908-1911.

10. Dorotta I, Basali A, Ritchey M, O'Hara JF Jr, Sprung J: Transurethral resection syndrome after bladder perforation: Anesth Analg 2003;97:1536-1538.

11. Manikandan R, Lynch N, Grills RJ. Percutaneous peritoneal drainage for intraperitoneal bladder perforations during transurethral resection of bladder tumors. J Endourol 2003;17:945-947.

12. Golab A1, Slojewski M, Gliniewicz B, et al. Laparoscopy as a treatment for intraperitoneal bladder injury. Scand J Urol Nephrol 2003;37:339-341.

13. Yap WT, Richie JP. Metastases from transitional cell carcinoma of the bladder masquerading as psoas abscess. J Urol 1980;123:959-960.

14. Mack D, Rammal E, Jakse G. [latrogenic tumor cell implantation in bladder cancer]. Urologe A 1988;27:99-104.

15. Ridwelski K, Meyer F, Hribaschek A, et al. Intraoperative and early postoperative chemotherapy into the abdominal cavity using gemcitabine may prevent postoperative occurence of peritoneal carcinomatosis. J Surg Oncol 2002;79:10-16. 